\title{
Organic matter and pH affect the analysis efficiency of ${ }^{31} \mathrm{P}-\mathrm{NMR}$
}

\author{
Wenqiang Zhang ${ }^{1}$, Xin Jin ${ }^{1,2}$, Nan Rong ${ }^{1,2}$, Jie Li ${ }^{1,2}$, Baoqing Shan ${ }^{1, *}$
}

1.. State Key Laboratory on Environmental Aquatic Chemistry, Research Center for Eco-Environmental Science, Chinese Academy of Science, Beijing 100085, China. E-mail: wqzhang@rcees.ac.cn

2.. University of Chinese Academy of Science, Beijing 100049, China

\section{A R T I C L E I N F O}

\section{Article history:}

Received 7 August 2015

Revised 9 October 2015

Accepted 12 October 2015

Available online 30 December 2015

\section{Keywords:}

${ }^{31} \mathrm{P}-\mathrm{NMR}$

$\mathrm{pH}$

Organic matter

Extraction rate

Sediment

\begin{abstract}
A B S T R A C T
Solution ${ }^{31} \mathrm{P}$ nuclear magnetic resonance spectroscopy $\left({ }^{31} \mathrm{P}-\mathrm{NMR}\right)$ is a useful method to analyze organic phosphorus (Po), but a general procedure for the analysis method is lacking. The authors used solution ${ }^{31} \mathrm{P}-\mathrm{NMR}$, which was found to be an effective method for analysis of Po in Haihe River sediment, to analyze the Po in the surface sediment in Eastern China at the regional scale, and found that the $\mathrm{NaOH}$-ethylenediaminetetraacetic acid (EDTA) extraction rate was affected by environmental factors. At the regional scale, the extraction rate showed a positive relationship with loss on ignition, when the extraction rate was lower than $60 \%$. The extraction rate had no relationship with the loss on ignition when the extraction rate was higher than $60 \%$. The extraction rate showed a negative relationship with $\mathrm{pH}$, which means that the extraction rate was higher in acidic sediment and lower in alkaline sediment. The ratio of TC/TN (the ratio of total carbon to total nitrogen) was considered to represent the origin of organic matter in the sediment. The extraction rate was high when the TC/TN ratio was lower than 20, meanwhile the extraction rate decreased as the TC/TN ratio increased. The results show that the origin of organic matter in sediment significantly affects the NaOH-EDTA extraction rate. This study will give theoretical support for building an effective and general solution ${ }^{31} \mathrm{P}-\mathrm{NMR}$ analysis method.

(c) 2015 The Research Center for Eco-Environmental Sciences, Chinese Academy of Sciences.
\end{abstract} Published by Elsevier B.V.

\section{Introduction}

Phosphorus (P), which includes inorganic phosphorus (Pi) and organic phosphorus (Po), is a vital nutrient source for aquatic organisms. Po constitutes a major component in some sediment, accounting for about $10 \%$ to $90 \%$ of total phosphorus (TP) in swamp sediments, everglades histosols and lake sediments (Hesse, 1962; D’Angelo and Webster, 1991; Sommers et al., 1972). Studies show that Po can be directly used (Phon-P can be directly used by Trichodesmium) or mineralized into (Pi) and then used by algae (Dyhrman et al., 2006; Wang and Pant, 2010).

Although Po is an important component in the sediment, due to the complexity of Po constituents and analytical limitations, the composition and transformation of Po remain poorly understood (Cade-Menun, 2005; Turner et al., 2005). Several analytical methods have been developed to analyze Po compounds, such as P fractionation (Hieltjes and Lijklema, 1980; Pierzynski, 2004). Although these methods have provided useful information to help understand P compounds and their cycling, they have not yielded sufficient insight into the identification of specific Po compounds (Brandes et al., 2007). Nuclear magnetic resonance (NMR) plays a key role in environmental research (Simpson et al., 2012). Phosphorus-31 nuclear magnetic resonance spectroscopy ( $\left.{ }^{31} \mathrm{P}-\mathrm{NMR}\right)$ distinguishes different $\mathrm{P}$ groups based on specific resonance frequencies, reflecting the chemical environment surrounding the P nuclei (Cardoza et al., 2004; Reitzel et al., 2006a, 2006b). Many Po species have been detected by ${ }^{31} \mathrm{P}-\mathrm{NMR}$, including phosphonates, orthophosphate

\footnotetext{
* Corresponding author. E-mail: bqshan@rcees.ac.cn (Baoqing Shan).
} 
monoesters, and orthophosphate diesters (Cade-Menun, 2005). Therefore, ${ }^{31} \mathrm{P}-\mathrm{NMR}$ is an ideal technique for use in analysis of Po species in marine or freshwater sediment (Cade-Menun, 2005; Simpson et al., 2011; Newman and Tate, 1980).

Po must be extracted from the sediment samples before it can be analyzed by ${ }^{31} \mathrm{P}-\mathrm{NMR}$. The extraction process must remove as much Po from the sediment sample as possible, and it must also keep the Po components untransformed in the extraction process. Thus the extraction processes are key factors in determining the effectiveness of the analysis. Many chemicals have been used as Po extractants, such as $\mathrm{H}_{2} \mathrm{O}$, $\mathrm{NaOH}, \mathrm{BD}, \mathrm{NaOH}$ and $\mathrm{NaF}, \mathrm{H}_{2} \mathrm{SO}_{4}, \mathrm{NaHCO}_{3}$ and Chelex (Reitzel et al., 2006a; Newman and Tate, 1980; Turner and Leytem, 2004; Sumann et al., 1998; Makarov et al., 2002). Cade-Menun and Preston (1996) examined various extractants and concluded that a mixture of $\mathrm{NaOH}$ and ethylenediaminetetraacetic acid (EDTA) was an ideal extractant, which gave excellent and stable recovery of the various $\mathrm{P}$ components. The presence of the chelating agent, EDTA, along with an organometallic component, increased the extraction efficiency of the $\mathrm{NaOH}$. Based on this conclusion, several $\mathrm{P}$ compounds have been detected using this extractant mixture (Turner et al., 2002; Sundareshwar et al., 2001; Hupfer et al., 1995).

The authors have optimized the preparation method for Po analysis using solution ${ }^{31} \mathrm{P}-\mathrm{NMR}$ (Zhang et al., 2013). A solution with $0.25 \mathrm{~mol} / \mathrm{L} \mathrm{NaOH}$ and $50 \mathrm{mmol} / \mathrm{L}$ EDTA was found to be the most appropriate extractant for the target sediment samples. There is significant diversity in the water ecosystems in Eastern China, as reflected in the rivers, wetlands, and lakes. Different water ecosystems have various types of sediments, which exhibit diverse $\mathrm{P}$ retention mechanisms. The extraction efficiency of $0.25 \mathrm{~mol} / \mathrm{L} \mathrm{NaOH}$ and $50 \mathrm{mmol} / \mathrm{L}$ EDTA for widely different types of sediments is unknown. Research on the extraction rates of the $0.25 \mathrm{~mol} / \mathrm{L} \mathrm{NaOH}$ and $50 \mathrm{mmol} / \mathrm{L}$ EDTA extractant for widely varying sediment samples is scarce, necessary and valuable. Therefore the goal of this study is to investigate the $\mathrm{NaOH}$ and EDTA extraction rate and the effect of environmental factors, such as $\mathrm{pH}$ and organic matter. The research will provide a theoretical foundation for building a ${ }^{31} \mathrm{P}-\mathrm{NMR}$ analysis method with broad applicability.

\section{Materials and methods}

\subsection{Site description and sampling}

A total of 89 sediment samples collected from Eastern China in September 2013 were analyzed in this study (Fig. 1). The sampling stations were located in rivers, wetlands and lakes, which were arranged from the Songhuajiang River to the Zhujiang River. Three surface sediments (about $5 \mathrm{~cm}$ depth) were collected by a Peterson grab sampler. Samples at the same site were pooled and homogenized to obtain a representative sample. On arrival at the laboratory, samples were freeze-dried at less than $-50^{\circ} \mathrm{C}$ (FD-1 freeze-dryer). Dried samples were ground and sieved through a $100-\mu \mathrm{m}$ mesh sieve. A representative sample was obtained by the quartering method, and then samples were placed in a sealed plastic bag and stored at room temperature until analysis.

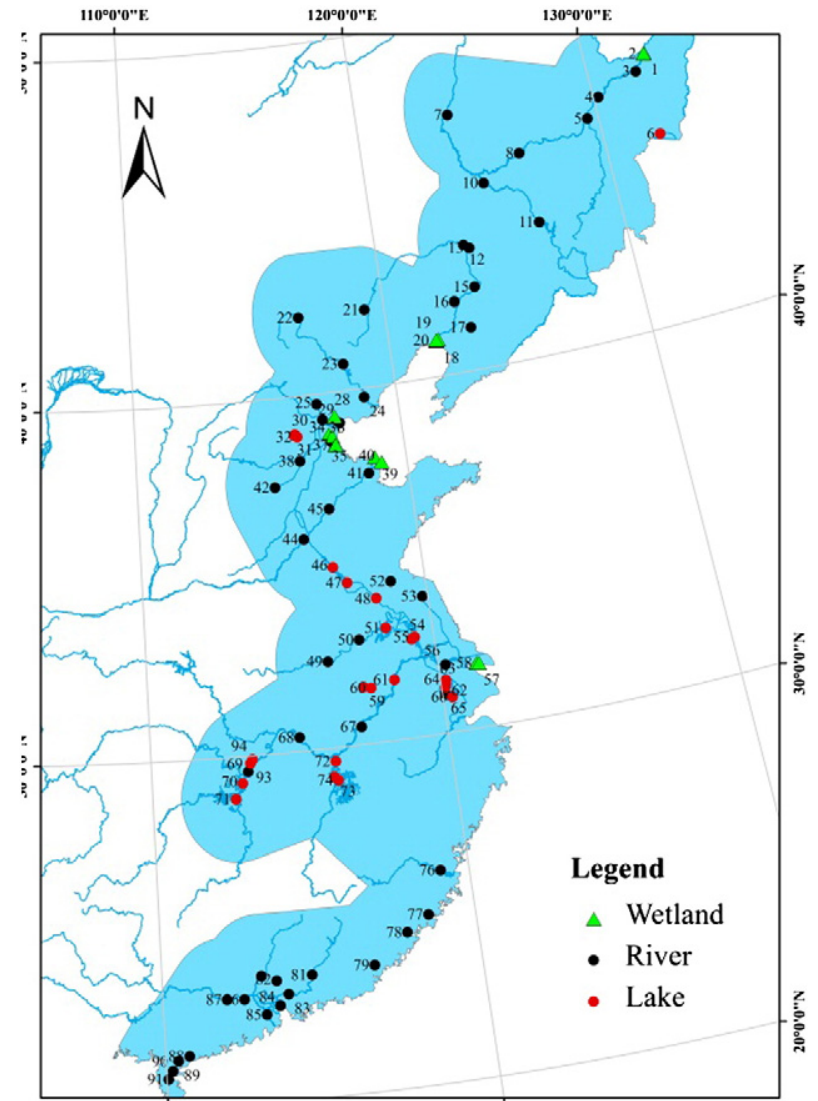

Fig. 1 - Location of the 89 sample sites in Eastern China. There sites were distributed in Heilongjiang Province, Liaoning Province, Hebei Province, Beijing Municipality, Tianjin Municipality, Shandong Province, Jiangsu Province, Shanghai Municipality, Anhui Province, Hubei Province, and Guangdong Province. There sites represent river, wetland and lake, which were the most common ecology systems in Eastern China. The region also has the largest population density and fastest economic development, and includes the Bohai Sea Economic Rim, Pearl River Delta Economic Rim and Yangtze River Delta Economic Rim.

\subsection{Sediment analysis and ${ }^{31} \mathrm{P}-\mathrm{NMR}$}

Organic matter (OM) in sediments was determined by loss-on-ignition (LOI) at $550^{\circ} \mathrm{C}$ for $4 \mathrm{~h}$ (Jensen et al., 1992). Total nitrogen (TN) in the sediment was analyzed by an elemental analyzer (Vario EL III, Elementar, Germany). The $\mathrm{pH}$ was determined by a pH electrode at a sediment:water ratio of 1:2.5 (Bai et al., 2009).

Po analysis in this study included two parts, the NaOH-EDTA extraction and the ${ }^{31} \mathrm{P}-\mathrm{NMR}$ analysis. Sediment samples, after being ground into powder and sieved through a $100 \mu \mathrm{m}$-mesh, were extracted with a solution of $\mathrm{NaOH}(0.25 \mathrm{~mol} / \mathrm{L})$ and EDTA $(0.05 \mathrm{~mol} / \mathrm{L})$ at room temperature at a ratio of 1:10 (sediment to extractant)(Zhang et al., 2013). An aliquot of extracts was used to analyze Pi (Pi in NaOH-EDTA) and TP (TP in NaOH-EDTA) using the molybdate colorimetry method before and after digestion by Potassium persulfate $\left(\mathrm{K}_{2} \mathrm{~S}_{2} \mathrm{O}_{8}\right)$. Total Po in the $\mathrm{NaOH}$-EDTA extract was determined from the difference between Pi and TP. The 


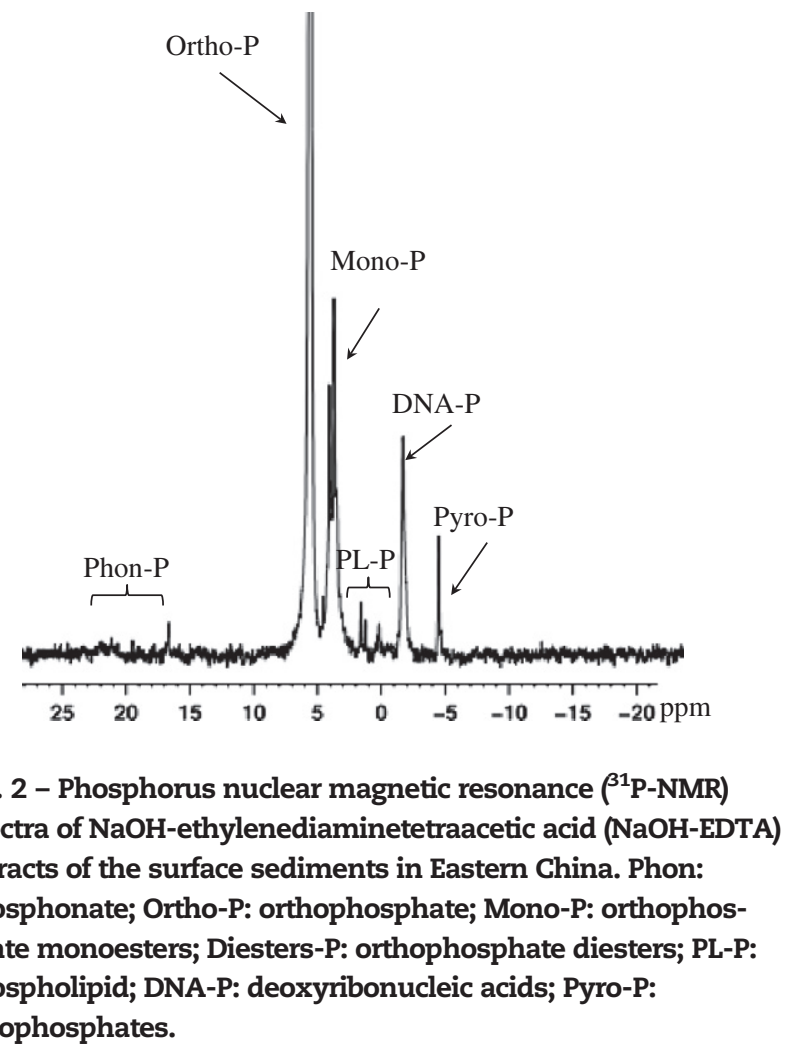

remaining solution was frozen and lyophilized before using for ${ }^{31} \mathrm{P}-\mathrm{NMR}$ analysis. Freezing the extracts has been shown not to alter the P composition (Hupfer et al., 1995, 2004).

Po might be lost through the process of freeze-drying and re-dissolution because of incomplete dissolution. However, lyophilized samples in this research were completely re-dissolved. So $0.3 \mathrm{~g}$ of the lyophilized $\mathrm{NaOH}$-EDTA extracts were re-dissolved with a mixed solution consisting of $0.6 \mathrm{~mL} \mathrm{D}_{2} \mathrm{O}$ and $0.1 \mathrm{~mL} 10 \mathrm{~mol} / \mathrm{L} \mathrm{NaOH}$. The Po solution was ultrasonicated for $30 \mathrm{~min}$, and then equilibrated for $5 \mathrm{~min}$. To reduce interference from paramagnetic ions, such as $\mathrm{Fe}^{3+}$ and $\mathrm{Mn}^{2+}, 2 \%(\mathrm{~V} / \mathrm{V})$ of $\mathrm{BD}\left(0.11 \mathrm{~mol} / \mathrm{L} \mathrm{NaHCO}\right.$ and $\left.0.11 \mathrm{~mol} / \mathrm{L} \mathrm{Na}_{2} \mathrm{~S}_{2} \mathrm{O}_{4}\right)$ was added to the extracts. The supernatants were centrifuged for $15 \mathrm{~min}$ at 14,000 r/min (rpm) (Eppendorf: Centrifuge 5418, Germany) and transferred to 5-mm NMR tubes. Solution ${ }^{31} \mathrm{P}-\mathrm{NMR}$ spectra were obtained using a Bruker $400 \mathrm{MHz}$ spectrometer (Bruker, Billerica, MA, USA) operating at $129.53 \mathrm{MHz}$ at $25^{\circ} \mathrm{C}$. We used a 90 degree observation pulse, relaxation delay $3 \mathrm{sec}$ and acquisition time 0.6 sec. Spectra were collected after between 3000 and 20,000 scans, depending on the concentration of Po (Beijing NMR center). Although the $\mathrm{T}_{1}$ relaxation times were not explicitly analyzed in this study, a $\mathrm{T}_{1}$ relaxation time of $3 \mathrm{sec}$ is thought to be adequate to obtain quantitative spectra for a variety of $\mathrm{P}$ forms from most samples (70\%) analyzed for $\mathrm{Mn}$ and Fe. Chemical shifts were recorded relative to $85 \% \mathrm{H}_{3} \mathrm{PO}_{4}$ standard ( $\left.\delta=0 \mathrm{ppm}\right)$. Signals were assigned to $\mathrm{P}$ species based on data in the literature (Cade-Menun, 2005; Turner et al., 2003b). Peak assignments were made using ${ }^{31} \mathrm{P}-\mathrm{NMR}$ chemical shifts of phosphonate (phon-P: 12 to $23 \mathrm{ppm}$ ), orthophosphate (ortho-P: 6 to $7 \mathrm{ppm}$ ), orthophosphate monoesters (mono-P: 4 to $6 \mathrm{ppm}$ ), phospholipids (lipids-P: 1 to $3 \mathrm{ppm}$ ), deoxyribonucleic acid phosphorus (DNA-P: $0 \mathrm{ppm}$ ), and pyrophosphate (pyro-P: -3.5 to $-4.5 \mathrm{ppm}$ ) (Fig. 2). The peak areas were calculated by visual inspection and an automated peak analysis tool. From the areas for the different $P$ species, the contribution of each $\mathrm{P}$ compound group was calculated relative to $\mathrm{TP}$ in the $\mathrm{NaOH}-\mathrm{EDTA}$ extract, determined by the molybdenum blue method (Cade-Menun, 2005; Turner et al., 2003b).

\section{Results and discussion}

\subsection{Characteristics of sediment in eastern China}

The characteristics of sediments are as following TP 87.3$6124.7 \mathrm{mg} / \mathrm{kg}$ with mean $549.54 \mathrm{mg} / \mathrm{kg}$, Po $6.1-319.8 \mathrm{mg} / \mathrm{kg}$ with mean $116.51 \mathrm{mg} / \mathrm{kg}$, loss-on-ignition $0.5 \%-16.7 \%$ with mean 5.70\%, TC/TN 6.1-107.8 with mean 16.16, and pH 4.6-8.9 with mean 7.78. The highest concentration of TP and Po was in the Haihe River System. The main reason for the high $\mathrm{P}$ concentration in the Haihe River System was that sewage was the predominant $\mathrm{P}$ source in this watershed. The $\mathrm{pH}$ also varied in different watersheds in Eastern China. The $\mathrm{NaOH}-\mathrm{EDT}$ A extraction rates ranged from $2 \%$ to $102 \%$, and the average extraction rate was $46 \%$ for different freshwater systems in Eastern China.

Four Po compositions were detected by solution ${ }^{31} \mathrm{P}-\mathrm{NMR}$ in the surface sediment in Eastern China, including phon-P, mono-P and diesters-P (PL-P and DNA-P). Mono-P is an important group of Po compounds in sediment that includes inositol P, sugar phosphates and mononucleotides. Inositol phosphates are considered to be the most abundant Po in aquatic sediment, which can be mineralized under anaerobic or aerobic conditions (Turner et al., 2002). In this study, the mean concentration of mono-P was $50.42 \mathrm{mg} / \mathrm{kg}$, making it the major Po in sediment. Diesters-P is a mixture of numerous compounds with varying lability (Turner et al., 2005). In this study, DNA-P and lipids-P were detected in the surface sediment. The concentrations of DNA-P and PL-P were 8.93 and $4.54 \mathrm{mg} / \mathrm{kg}$, respectively. The phon-P, which was only detected in some surface sediment, is considered a chemically stable compound because of the direct C-P bond (Turner et al., 2005); the concentration of phon-P was $2.90 \mathrm{mg} / \mathrm{kg}$.

\subsection{EDTA-NaOH extraction rate and characteristics of sediment}

According to comprehensive analysis, the characteristics of LOI, $\mathrm{pH}$ and the ratio of $\mathrm{TC}$ to TN affect the NaOH-EDTA extraction rate (ER). The relationship of LOI and ER is shown in Fig. 3a. The ER were positively related with LOI for ER under $60 \%\left(R^{2}=0.10, p<0.05\right)$. That indicated the ER of Po increased with increasing LOI, and that there was no relationship between LOI and the ER of Po when the ER was above $60 \%$. Studies have shown that Po is positively correlated with LOI in the sediments. Therefore the ER of $\mathrm{NaOH}$-EDTA increased with increasing LOI. The main reason for this phenomenon is that the increase of Po ER affects the total ER in eastern region sediments. For some sediments, the ER had no relationship with LOI when the ER was above $60 \%$. The reason for this phenomenon was that most of Po was extracted when the ER was above $60 \%$, and the remaining $\mathrm{P}$ was the ortho-P and acid extract-P (Cade-Menun, 2005; Turner et al., 2005; Cade-Menun and Liu, 2013). 

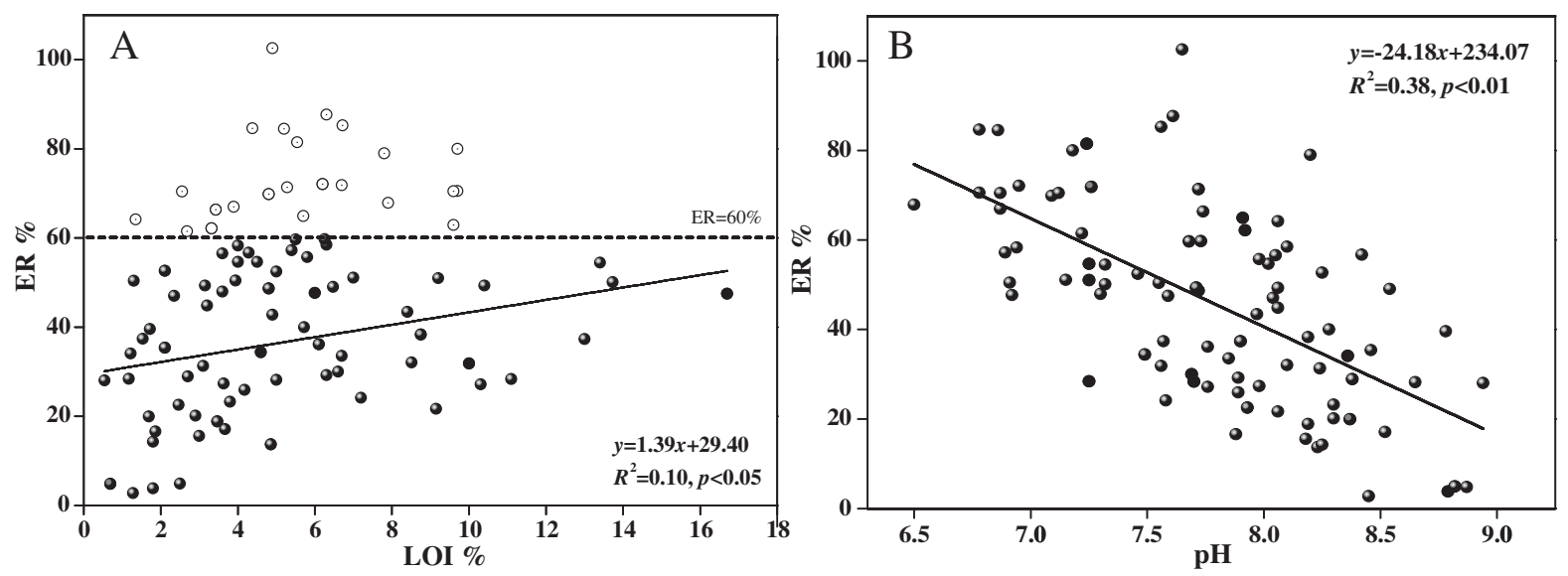

Fig. 3 - EDTA-NaOH extraction rate plotted against the characteristics of the sediment. (a) extraction rate (ER) and the Loss on ignition (LOI) of the sediment. Positive relationship was found between ER and LOI under the condition of ER under $60 \%$ $\left(R^{2}=0.10, p<0.05\right)$. The ER and the LOI show no correlation when the ER exceeds $60 \%$. (b) ER and pH of the sediment. Negative relationship was found between EDTA-NaOH extraction rate and the $\mathrm{pH}$ of the sediments $\left(R^{2}=0.38, p<0.01\right)$, which means the ER was increased with the decrease of the $\mathrm{pH}$ of the sediment.

The ER had a negative relationship with $\mathrm{pH}$, meaning that the ER decreased as the $\mathrm{pH}$ increased $\left(\mathrm{R}^{2}=0.38, p<0.01\right)$ (Fig. 3b). For all sediments, the $\mathrm{pH}$ ranged from 6.5 to 9.0, and the ER ranged from $2 \%$ to $102 \%$. The lowest ER was found for the Yellow River sediment sample. The Yellow River sediment samples were composed of fine sand, which had low Po. The same results were also discovered in soil samples, but not in sediments at the regional scale (McDoell and Stewart, 2006; Dou et al., 2009). Turner et al. (2003a) suggested that higher adsorptive surface area and lower microbial activity are beneficial for the existence of Po. On the contrary, alkaline soil, which is mainly characterized by $\mathrm{CaCO}_{3}$, has a lower ability for holding organic carbon and Po, so the NaOH-EDTA had a weak ER in extracting Po from calcicolous soil (Turner et al., 2003a). In this study, the reason that ER and pH show a positive relationship is that acidic sediment, which has a higher ability to hold organic matter than alkaline sediment, was distributed in southern China. So the ER was higher in acidic sediment than that in alkaline sediment. However, the mechanism for the difference in ER in different types of sediments needs to be studied in more depth in terms of sediment physicochemical structure and composition and $\mathrm{NaOH}-E D T A$ extraction mechanism.

The ratio of $\mathrm{TC}$ to $\mathrm{TN}$ is another factor affecting the $\mathrm{NaOH}$-EDTA extraction ratio (Fig. 4). For freshwater sediment, the ratio of $\mathrm{TC} / \mathrm{TN}$ was an indicator for the source of the organic matter. Low aquatic plants are enriched in protein, giving a TC/TN ratio under 7 . However, the ratio of TC/TN in terrestrial vascular plants is usually greater than 20 . Therefore, the organic matter most likely originates from the decomposition of aquatic plants when the $\mathrm{TC} / \mathrm{TN}$ ratio is under 7. When the ratio of TC/TN is greater than 20, terrestrial input is the source of the organic matter in the freshwater sediment (Chen and Wan, 2000; Reitzel et al., 2007).

The ratio of $\mathrm{TC} / \mathrm{TN}$ (organic matter origin) showed a positive relationship with the $\mathrm{ER}\left(\mathrm{R}^{2}=0.65, p<0.01\right)$. The ER decreased as the TC/TN ratio increased, which means the $\mathrm{NaOH}-\mathrm{EDTA}$ ER for the terrestrial input in sediment was lower, and the ER for the sediment originating from aquatic plants was higher. Large amounts of wastewater input lead to the accumulation of $\mathrm{P}$ in the sediment, because of the rapid socio-economic development in Eastern China. The complex composition of man-made pollutant input will influence the composition of Po in the sediment, and affect the NaOH-EDTA extraction rate. For the aquatic plant enriched sediment, most of the Po originated from the decomposition of aquatic plants, such as algae, and the composition of Po was relatively simple. Thus, the $\mathrm{NaOH}$-EDTA extraction rate was high. The present work is a simple study on the effect of sediment type on $\mathrm{NaOH}-\mathrm{EDTA}$ extraction rate, and much more in-depth study needs to be carried out in the future to more fully elucidate the NaOH-EDTA extraction mechanism.

Solution ${ }^{31} \mathrm{P}-\mathrm{NMR}$ is a useful method for Po analysis. However, the $\mathrm{NaOH}$-EDTA extraction rate was found to be affected by the sediment physico-chemical properties at the large regional scale. At the regional scale, the ER showed a positive relationship with LOI, when the ER was lower than $60 \%$. The ER had no relationship with LOI when the ER was higher than $60 \%$. ER showed a negative

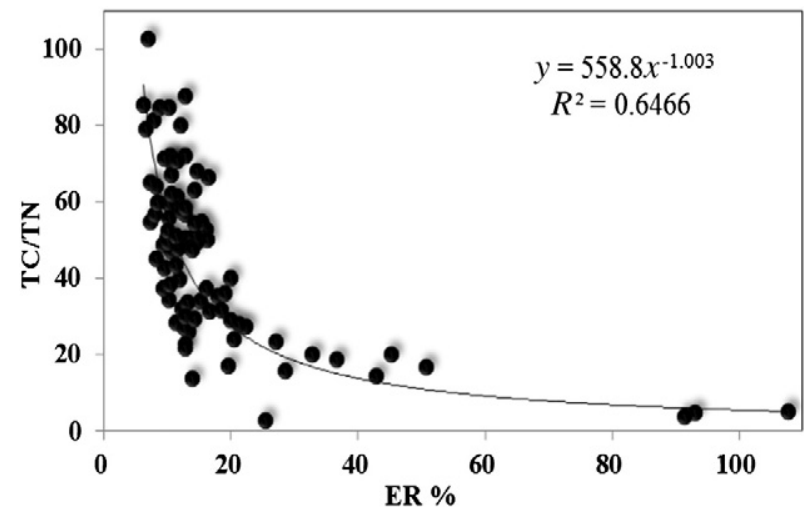

Fig. 4 - The ratio of total carbon to total nitrogen (TC/TN) ratio and extraction rate (ER) show an exponential relationship $\left(R^{2}=0.6466\right)$. 
relationship with $\mathrm{pH}$, meaning that the ER was higher in acidic sediments, while the opposite was the case in alkaline sediments. The ratio of $\mathrm{TC} / \mathrm{TN}$ was considered to represent the origin of organic matter in the sediment. The ER was high when the TC/TN ratio was lower than 20 , but the ER decreased as the ratio of TC/ TN increased. The results show that the origin of organic matter in sediment can significantly affect the $\mathrm{NaOH}$-EDTA extraction rate.

\section{Conclusions}

This research study has used $\mathrm{NaOH}-\mathrm{EDTA}$ as extractant to analyze the $\mathrm{P}$ composition in the surface sediment in Eastern China by solution ${ }^{31} \mathrm{P}-\mathrm{NMR}$. The results show that the extraction rate was affected by environmental factors. The main conclusions are as follows: At the regional scale, the ER showed a positive relationship with LOI, when the ER was lower than $60 \%$. The ER had no relationship with LOI when the ER was higher than $60 \%$.

ER showed a negative relationship with $\mathrm{pH}$, meaning that the ER was higher in acidic sediments, and the opposite was the case in alkaline sediments.

The TC/TN ratio was considered to represent the origin of organic matter in the sediment. The ER was high when the TC/TN ratio was lower than 20 , but the ER decreased as the ratio of TC/TN increased.

The results show that the origin of organic matter in sediment significantly affects the ER of $\mathrm{NaOH}$-EDTA at the regional scale.

\section{Acknowledgments}

This work was supported by the National Natural Science Foundation of China (No. 21507146) and the special fund from the State Key Joint Laboratory of Environment Simulation and Pollution Control (Research Center for Eco-environmental Sciences, Chinese Academy of Sciences) (No. 15Z01ESPCR). We thank Dr. Jingxin Yang and Dr. Xiaogang Niu for ${ }^{31} \mathrm{P}-\mathrm{NMR}$ analysis (Beijing Nuclear Magnetic Resonance Center). We also thank Xuehong Kong, Shou Yuan, Bozhen Zhang and Jianlin Bi for collecting the samples.

\section{R E F E R E N C E S}

Bai, X.L., Ding, S.M., Fan, C.X., Liu, T., Shi, D., Zhang, L., 2009. Organic phosphorus species in surface sediments of a large shallow, eutrophic lake, Lake Taihu, China. Environ. Pollut. 157 (8-9), 2507-2513.

Brandes, J.A., Ingall, E.D., Paterson, D., 2007. Characterization of minerals and organic phosphorus species in marine sediments using soft X-ray fluorescence spectromicroscopy. Mar. Chem. 103 (3-4), 250-265.

Cade-Menun, B.J., 2005. Characterizing phosphorus in environmental and agricultural samples by ${ }^{31} \mathrm{P}$ nuclear magnetic resonance spectroscopy. Talanta 66 (2), 359-371.

Cade-Menun, B.J., Liu, C.W., 2013. Solution phosphorus-31 nuclear magnetic resonance spectroscopy of soils from 2005 to 2013: a review of sample preparation and experimental parameters. Soil Sci. Soc. Am. J. 78 (1), 19-37.
Cade-Menun, B.J., Preston, C.M., 1996. A comparison of soil extraction procedures for ${ }^{31} \mathrm{P}$ NMR spectroscopy. Soil Sci. 161 (11), 770-785.

Cardoza, L.A., Korir, A.K., Otto, W.H., Wurrey, C.J., Larive, C.K., 2004. Applications of NMR spectroscopy in environmental science. Prog. Nucl. Magn. Reson. Spectrosc. 45 (3), 209-238.

Chen, J.A., Wan, G.J., 2000. Environmental records in recent sediments of lake Chenhai, Yunnai province. Acta Mineral. Sin. 20 (2), 112-116.

D'Angelo, D.J., Webster, J.R., 1991. Phosphorus retention in stream draining pine and hardwood catchments in the southern Appalachian Mountains. Freshw. Biol. 26 (3), 335-345.

Dou, Z.X., Ramberg, C.F., Toth, J.D., Wang, Y., Sharpley, A.N., Boyd, S.E., et al., 2009. Phosphorus speciation and sorption-desorption characteristics in heavily manured soils. Soil Sci. Soc. Am. J. 73 (1), 93-101.

Dyhrman, S.T., Chappell, P.D., Haley, S.T., Moffett, J.W., Orchard, E.D., Waterbury, J.B., et al., 2006. Phosphonate utilization by the globally important marine diazotroph Trichodesmium. Nature 439 (7072), 68-71.

Hesse, P.R., 1962. Phosphorus fixation in mangrove swamp muds. Nature 193, 295-296.

Hieltjes, A.H.M., Lijklema, L., 1980. Fractionation of inorganic phosphorus in calcareous sediments. J. Environ. Qual. 9 (3), 405-407.

Hupfer, M., Gächter, R., Ruegger, H., 1995. Polyphosphate in lake sediments: ${ }^{31} \mathrm{P}$ NMR spectroscopy as a tool for its identification. Limnol. Oceanogr. 40 (3), 610-617.

Hupfer, M., Rübe, B., Schmieder, P., 2004. Origin and diagensis of polyphosphate in lake sediments: ${ }^{31} \mathrm{P}-\mathrm{NMR}$ study. Limnol. Oceanogr. 49 (1), 1-10.

Jensen, H.S., Kristensen, P., Jeppesen, E., Skytthe, A., 1992. Iron: phosphorus ratio in surface sediment as an indicator of phosphate release from aerobic sediments in shallow lakes. Hydrobiologia 235/236 (1), 731-743.

Makarov, M.I., Haumaier, L., Zech, W., 2002. The nature and origins of diester phosphates in soils: a ${ }^{31} \mathrm{P}-\mathrm{NMR}$ study. Biol. Fertil. Soils 35 (2), 136-146.

McDoell, R.W., Stewart, I., 2006. The phosphorus composition of contrasting soils in pastoral native and forest management in Otago, New Zealand: sequential extraction and ${ }^{31} \mathrm{P}$ NMR. Geoderma 130 (1-2), 176-189.

Newman, R.H., Tate, K.R., 1980. Soil phosphorus characterization by ${ }^{31} \mathrm{P}$ nuclear magnetic resonance. Commun. Soil Sci. Plant 11 (9), 835-842.

Pierzynski, G.M., 2004. Methods of phosphorus analysis for soils, sediments, residuals, and waters. Southern Cooperative Series Bulletin No.396. North Carolina State University Press, Raleigh.

Reitzel, K., Ahlgren, J., Gogoll, A., Jensen, H.S., Rydin, E., 2006a. Characterization of phosphorus in sequential extracts from lake sediments using ${ }^{31} \mathrm{P}$ nuclear magnetic resonance spectroscopy. Can. J. Fish. Aquat. Sci. 63 (8), 1686-1699.

Reitzel, K., Ahlgren, J., Gogoll, A., Rydin, E., 2006b. Effects of aluminum treatment on phosphorus, carbon, and nitrogen distribution in lake sediment: a ${ }^{31}$ P NMR study. Water Res. 40 (4), 647-654.

Reitzel, K., Ahlgren, J., DeBrabandere, H., Waldebäck, M., Gogoll, A., Tranvik, L., et al., 2007. Degradation rates of organic phosphorus in lake sediment. Biogeochemistry 82 (1), 15-28.

Simpson, A.J., McNally, D.J., Simpson, M.J., 2011. NMR spectroscopy in environmental research: from molecular interactions to global processes. Prog. Nucl. Magn. Reson. Spectrosc. 58, 97-175.

Simpson, A.J., Simpson, M.J., Soong, R., 2012. Nuclear magnetic resonance spectroscopy and its key role in environmental research. Environ. Sci. Technol. 46 (21), 11488-11496.

Sommers, L.E., Harris, R.F., Williams, J.D.H., Armstrong, D.E., Syers, J.K., 1972. Fractionation of organic phosphorus in lakes sediments. Soil Sci. Soc. Am. J. 36, 51-54.

Sumann, M., Amelung, W., Haumaier, L., Zech, W., 1998. Climatic effects on soil organic phosphorus in the north American great 
plains identified by phosphorus-31 nuclear magnetic resonance. Soil Sci. Soc. Am. J. 62 (6), 1580-1586.

Sundareshwar, P.V., Morris, J.T., Pellechia, P.J., Cohen, H.J., Porter, D.E., Jones, B.C., 2001. Occurrence and ecological implications of pyrophosphate in estuaries. Limnol. Oceanogr. 46 (6), 1570-1577.

Turner, B.L., Leytem, A.B., 2004. Phosphorus compounds in sequential extracts of animal manures: chemical speciation and a novel fractionation procedure. Environ. Sci. Technol. 38 (22), 6101-6108.

Turner, B.L., Papházy, M.J., Haygarth, P.M., McKelvie, I.D., 2002. Inositol phosphates in the environment. Philos. Trans. R. Soc. Lond. Ser. B Biol. Sci. 357 (1420), 449-469.

Turner, B.L., Cade-Menun, B.J., Westermann, D.T., 2003a. Organic phosphorus composition and potential bioavailability in semi-arid arable soils of the western United States. Soil Sci. Soc. Am. J. 67 (4), 1168-1179.
Turner, B.L., Mahieu, N., Condron, L.M., 2003b. The phosphorus composition of temperate pasture soils determined by $\mathrm{NaOH}-\mathrm{EDTA}$ extraction and solution ${ }^{31} \mathrm{P}$ NMR spectroscopy. Org. Geochem. 34 (8), 1199-1210.

Turner, B.L., Cade-Menun, B.J., Condron, L.M., Newman, S., 2005. Extraction of soil organic phosphorus. Talanta 66 (2), 294-306.

Wang, J.Y., Pant, H.K., 2010. Identification of organic phosphorus compounds in the Bronx River bed sediments by phosphorus-31 nuclear magnetic resonance spectroscopy. Environ. Monit. Assess. 171 (1-4), 309-319.

Zhang, W.Q., Shan, B.Q., Zhang, H., Tang, W.Z., 2013. Assessment of preparation methods for organic phosphorus analysis in phosphorus-polluted Fe/Al-rich Haihe River sediments using solution ${ }^{31} \mathrm{P}-\mathrm{NMR}$. PLoS One 8, e76525. 